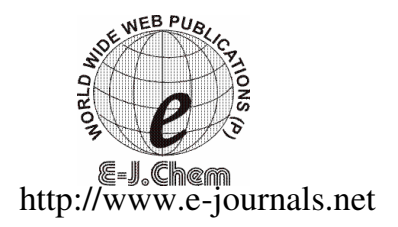

ISSN: 0973-4945; CODEN ECJHAO

E-Journal of Chemistry 2010, 7(1), 149-156

\title{
Synthesis of New Chiral and Nonchiral Pyrido $[3,2-e],[1,3,4]$ oxadiazine Derivatives
}

\author{
L. S. SHET ${ }^{\S *}$, A. R. SHELAR ${ }^{\S}$ and F. V. MANVI \\ ${ }^{\S}$ Chemistry Department, Shivaji University, Kolhapur, India. \\ KLE college of Pharmacy, Belgaum, India. \\ lsshet123@rediffmail.com
}

Received 29 March 2009; Revised 15 June 2009; Accepted 9 July 2009

\begin{abstract}
A chiral series of 6,7-dichloro-3-[3-(2,2-dihalovinyl)-2,2dimethylcyclopropyl] -1H-pyrido [3,2-e],[1,3,4] oxadiazines (a-f) and a nonchiral series of 3-substituted, 6,7-dichloro-1H-pyrido [3,2-e][1,3,4] oxadiazines (a-g) have been synthesized. The synthesized compounds were characterized by IR, ${ }^{1} \mathrm{H}-\mathrm{NR}, \mathrm{HPLC}$ and mass spectral data.
\end{abstract}

Keywords: $1 \mathrm{H}$-pyrido, Chiral, Oxadiazine, Phenyl sulfanyl, Naphthyl sulfanyl.

\section{Introduction}

Oxadiazines are interesting ${ }^{1}$ and promising heterocyclic compounds. A diversity of biological effects is associated with oxadiaxzines bearing hetero atoms at 1, 2, 4 or 1,3,4 positions. $6 H-1,2$, 4-oxadiazine-3, 5- $(2 H, 4 H)$-dione, the 6-oxa analogue of uracil, has been shown to significantly inhibit growth in several bacterial strains while not being highly inhibitory to mammalian cells ${ }^{2}$.

1, 3, 4-Oxadiazine derivatives exhibit cardiovascular, antibacterial, plant growth regulating, miticidal and nematocidal, acricidal, insecticidal and anticonvulsive activities ${ }^{3,4}$. In addition, oxadiazines are useful intermediates in the synthesis of tenidap prodrugs or $\beta$-lactam antibiotics, in particular into the synthesis of carbapenems and penems 5 . The invention relates to an optically active form of a pyridyl- $4 H-1,2$, 4-oxadiazine derivative ${ }^{7}$, to the therapeutical use thereof and to a pharmaceutical compositions containing the compound as active ingredient. More particularly, the invention relates to the (-) enantiomer of 5,6-dihydro-5-[(1-piperidinyl)-methyl-3-(3-pyridyl)- $4 \mathrm{H}$ $1,2,4$-oxadiazine and its acid addition salts as well as the use of these chemical compounds in the treatment of vascular diseases. It is reported in literature ${ }^{8}$ that indoxacarb, an oxadiazine insecticide blocks insect neuronal sodium channels. Claude Bonnes and co-workers ${ }^{9}$ reported in their invention that 3-oxo-5, 6-dihydro-1, 2, 4-oxadiazines useful as antiandrogenic agents. 4substituted 5, 6-dihydro-2-o-hydroxyphenyl-4H-1, 3, 4-oxadiazine-5-ones ${ }^{10}$ were reported in literature as potential psychopharmacological drugs. The promising therapeutic potential of this class of compounds prompted us to synthesize novel derivatives of several 1,3, 4-oxadiazines. 


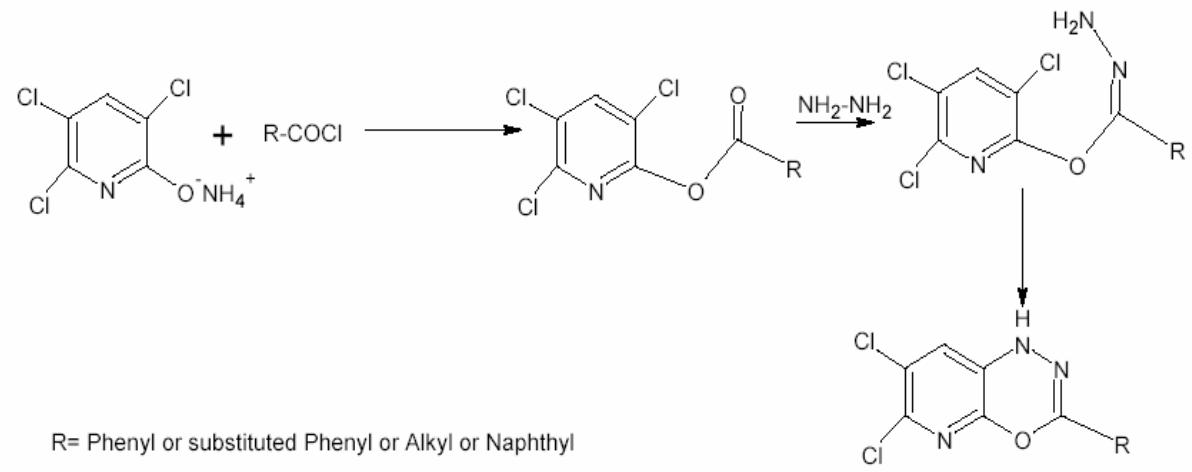

Scheme 1

\section{Experimental}

Melting points were determined on a LABINDIA MR.VIS visual melting range apparatus and are uncorrected. Reactions monitored by using Shimadzu SPD 10AV HPLC. Solvent system (mobile phase) acetonitrile -methanol-water (60:30:10) and $240 \mathrm{~nm}$. HPLC column used was $\mathrm{C}-18$ and flow rate maintained was $1 \mathrm{~mL} / \mathrm{min}$. IR spectra in $\mathrm{KBR}\left(\mathrm{cm}^{-1)}\right.$ were recorded on Jasco FT/IR-410 series spectrophotometer and ${ }^{1} \mathrm{H}$ NMR spectra were recorded $\left(\right.$ DMSO- $\mathrm{d}_{6}$ ) on a Bruker $200 \mathrm{MHz}$ spectrometer using TMS as internal standard (chemical shifts are expressed in $\delta$ ppm.). GC-MS spectra were recorded on Polaris Q mass detector.

\section{Chiral pyrido oxadiazine derivatives}

6,7-Dichloro-3-[3-(2,2-dibromovinyl)-2,2-dimethylcyclopro- pyl]-1H-pyrido[3,2-e] $[1,3,4]$ oxadiazine $(1 R, 3 R$ isomer $)(a)$<smiles>CC1(C)[C@H](C=C(Br)Br)[C@H]1C1=NNc2cc(Cl)c(Cl)nc2O1</smiles>

In a set up of 3 necked round bottom flask with magnetic stirrer, $150 \mathrm{~mL}$ methanol, 0.05 moles of 3,5,6-trichloropyridin-2-yl (1R, 3R)-3-(2,2-dibromovinyl)-2,2-dimethylcyclopropanecarboxylate and $0.5 \mathrm{~g}$ PTSA was taken. It was slurry. This mass was cooled to $20{ }^{\circ} \mathrm{C}$ by external cooling and to this 0.055 moles of hydrazine hydrate $(80.0 \%$ solution) was added. Addition was exothermic and thin slurry converted into thick white slurry. This was maintained at $20-30{ }^{\circ} \mathrm{C}$ for $4 \mathrm{~h}$. Filtered the mass and washed with $50 \mathrm{~mL}$ of methanol. The hydrazonoate isolated yield was $97.5 \%$.

In a reaction set up of single necked flask, magnetic stirring and oil heating system, $5.0 \mathrm{~g}$ (0.01 mole) of above prepared hydrazonoate, $25 \mathrm{~mL}$ dimethyl acetamide (DMAC) solvent and $0.7 \mathrm{~g}$ of $\mathrm{K}_{2} \mathrm{CO}_{3}$ as acid binder was taken. This was heated to $115-120^{\circ} \mathrm{C}$ and maintained for 6 h. Distilled out DMAC under reduced pressure and to the left over residue added water and filtered. The filtered solid dried and crystallized with $20 \mathrm{~mL}$ methanol. Crystallized yield was $65.78 \%$. Off-white crystalline solid; melting point was $180-182^{\circ} \mathrm{C}$.

Spectral data

IR (KBr) $v_{\max }$ in cm $^{-1}$ : 3068(C-H str.), 549-662 (C-Br str.), 1462 ( C=C gem. str.) 
6,7-Dichloro-3-[3-(2,2-dichlorovinyl)-2,2-dimethylcyclopro-pyl]-1H-pyrido [3,2-e] $[1,3,4]$ oxadiazine. $\quad(55: 45$ cis: trans isomer $)(\boldsymbol{b})$<smiles>CC1(C)C(C=C(Cl)Cl)C1C1=NNc2cc(Cl)c(Cl)nc2O1</smiles>

In a set up of 3 necked round bottom flask with magnetic stirrer, $150 \mathrm{~mL}$ methanol, 0.05 mole of 3,5,6-trichloropyridin-2-yl-3-(2,2-dichlorovinyl)-2,2-dimethylcyclopropanecarboxylate (cis:trans - 55:45) and $0.5 \mathrm{~g}$ PTSA was taken. It was slurry. This mass was cooled to $18-20{ }^{\circ} \mathrm{C}$ by external cooling and to these 0.055 moles of hydrazine hydrate $(80.0 \%$ solution) was added. Addition was exothermic and thin slurry converted into thick white slurry. This was maintained at $20-30{ }^{\circ} \mathrm{C}$ for $4 \mathrm{~h}$. Filtered the mass and washed with $50 \mathrm{~mL}$ of methanol. The yield of hydrazonoate isolated was $18 \mathrm{~g}$ (89.5\% yield).

In a reaction set up of single necked flask, magnetic stirring and oil heating system, $5.0 \mathrm{~g}$ (0.012 mole) of above prepared hydrazonoate, $25 \mathrm{~mL}$ dimethyl acetamide (DMAC) solvent and $0.7 \mathrm{~g}$ of $\mathrm{K}_{2} \mathrm{CO}_{3}$ as acid binder was taken. This was heated to $115-125{ }^{\circ} \mathrm{C}$ and maintained for $7 \mathrm{~h}$. DMAC was distilled out under reduced pressure and to the left over residue, water was added and filtered. The filtered solid dried and crystallized with $25 \mathrm{~mL}$ methanol. Crystallized yield was $22.7 \%$. Off-white crystalline solid; melting point was $258-259^{\circ} \mathrm{C}$.

6, 7-Dichloro-3-[3-(2,2-dichlorovinyl)-2,2-dimethylcyclopro-pyl]-1H-pyrido [3,2-e] [1,3,4] Oxadiazine (Trans isomer)(c)

Procedure followed for this compound is same as compound (b), but staring ester for this synthesis was 3, 5, 6-trichloropyridin-2-yl -3-(2, 2-dichlorovinyl)-2, 2-dimethyl cyclopropanecarboxylate $(99.0 \%$ trans isomer). The yield was off-white crystalline solid $(12.0 \%)$; melting point was $236-237^{\circ} \mathrm{C}$.

6,7-Dichloro-3-[3-(2,2-dichlorovinyl)-2,2-dimethylcyclopro- pyl]-1H-pyrido [3,2e][1,3,4] oxadiazine (SS isomer) $(\mathrm{d})$

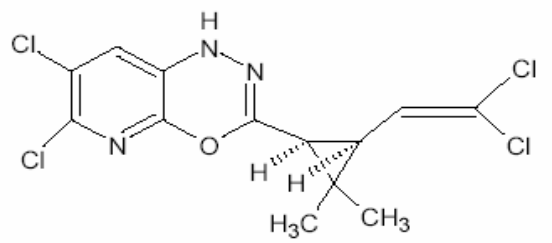

Procedure followed for this compound was exactly same as compound (b), but staring ester for this synthesis was 3, 5, 6-trichloropyridin-2-yl (1S, 3S)-3-(2, 2- dichlorovin-yl)-2, 2 dimethyl cyclopropanecarboxylate $(99.0 \% \mathrm{SS}$ isomer). The yield of off-white crystalline solid was $22.0 \%$, melting point was $179-181^{\circ} \mathrm{C}$.

Spectral data

IR (KBr) $v_{\max }$ in $\mathbf{c m}^{-1}$ : 3068 (-NH str.), 2969 (C-H str.), 1627(C=C aromatic.), 818-847 (C-Cl str.)

${ }^{1} \mathbf{H}$ NMR (DMSO-d $): \delta, 1.24\left(3 \mathrm{H}, \mathrm{s}, \mathrm{CH}_{3}\right), 1.28\left(3 \mathrm{H}, \mathrm{s}, \mathrm{CH}_{3}\right), 1.73(1 \mathrm{H}, \mathrm{d}),, 2.01(1 \mathrm{H}, \mathrm{d})$, 6.31(1H,d, - vinyl), 7.27 (1H, aromatic), 6.35(1H, s, NH)

GC-MS: $368(\mathrm{M}+1$ peak). 
6,7-Dichloro-3-[3-(2,2-dichlorovinyl)-2,2-dimethylcyclo-propyl]-1H-pyrido[3,2-e] [1,3,4]oxadiazine (RR isomer)(e)<smiles>CC1(C)[C@H](C=C(Cl)Cl)[C@H]1C1=NNc2cc(Cl)c(Cl)nc2O1</smiles>

In a set up of 3 necked round bottom flask with magnetic stirrer, $150 \mathrm{~mL}$ methanol, 0.05 moles of 3,5,6-trichloropyridin-2-yl (1R, 3R)-3-(2,2-dichlorovinyl)-2,2-dimethylcyclopropanecarboxylate and $0.5 \mathrm{~g}$ PTSA was taken. It was slurry. This mass was cooled to $15-20{ }^{\circ} \mathrm{C}$ by external cooling and to these 0.055 moles of hydrazine hydrate $(80.0 \%$ solution) was added. Addition was exothermic and thin slurry converted into thick white slurry. This was maintained at $20-30{ }^{\circ} \mathrm{C}$ for $4 \mathrm{~h}$. Filtered the mass and washed with $50 \mathrm{~mL}$ of methanol. The yield of hydrazonoate isolated was $89 \%$

In a reaction set up of single necked flask, magnetic stirring and oil heating system, $5.0 \mathrm{~g}(0.012 \mathrm{~mole})$ of above prepared hydrazonoate and $25 \mathrm{~mL}$ pyridine was taken and heated to reflux at $115-116{ }^{\circ} \mathrm{C}$ and maintained for $6 \mathrm{~h}$. Pyridine was distilled out under reduced pressure and to the left over residue $50 \mathrm{~mL}$ dichloromethane solvent $+50 \mathrm{~mL}$ water was added. Separated layers and organic layer washed with $25 \mathrm{~mL}$ of dilute sodium carbonate solution followed by water. Organic layer concentrated and crystallized with $10 \mathrm{~mL}$ of isopropyl alcohol. The yield of off-white crystalline solid was $34 \%$, melting point was $160-162{ }^{\circ} \mathrm{C}$.

6,7-Dichloro-3-[3-(2,2-dichlorovinyl)-2,2-dimethylcyclopro- pyl ]-1H-pyrido[3,2e][1,3,4] oxadiazine $(R R+S S-$ isomer $)(f)$

Synthesis procedure remains same as compound (e), but only change is that starting ester is 3 , 5, 6-trichloropyridin-2-yl-3- (2,2-dichlorovinyl)-2,2-dimeth- yl cyclopropane carboxylate (RR $+\mathrm{SS}$ isomer). The yield of off-white crystalline solid was $35 \%$, melting point was $147-148{ }^{\circ} \mathrm{C}$.

\section{Nonchiral pyrido oxadiazine derivatives}

6,7-Dichloro-3-\{[(2,5-dichlorophenyl)sulfanyl]methyl\}-1H-pyrido [3,2-e][1,3,4] oxadiazine $(\boldsymbol{a})$<smiles>Clc1ccc(Cl)c(SCC2=NNc3cc(Cl)c(Cl)nc3O2)c1</smiles>

In a set up of single necked round bottom flask with magnetic stirrer, $50 \mathrm{~mL}$ of methanol, 0.006 moles of 3,5,6-trichloropyridin-2-yl [(2,5-dichlorophenyl) sulfanyl] acetate and 0.1g PTSA was taken. It was slurry. This mass was cooled to $18-20{ }^{\circ} \mathrm{C}$ by external cooling and to these 0.007 moles of hydrazine hydrate $(80.0 \%$ solution) was added. Addition was exothermic and thin slurry converted into thick white slurry. This was maintained at $20-30{ }^{\circ} \mathrm{C}$ for $4 \mathrm{~h}$. Filtered the mass and washed with $50 \mathrm{~mL}$ of methanol. The yield of hydrazonoate yield was $93.0 \%$.

In a reaction set up of single necked flask, magnetic stirrer and oil heating system, $2.0 \mathrm{~g}$ (0.005 mole) of above prepared hydrazonoate, $25 \mathrm{~mL}$ DMAC solvent and $0.23 \mathrm{~g} \mathrm{of}_{2} \mathrm{CO}_{3}$ was added as acid binder. This was heated to $140-145^{\circ} \mathrm{C}$ and maintained for $4 \mathrm{~h}$.

DMAC was distilled out under reduced pressure and to the left over residue water was added and filtered. The filtered solid dried and crystallized with $100 \mathrm{~mL}$ methanol, as solubility is very poor. The yield of buffer-white crystalline solid was $74 \%$, melting point was $211-212{ }^{\circ} \mathrm{C}$. 
Spectral data

IR (KBr) $\boldsymbol{v}_{\max }$ in $\mathbf{~ c m}^{-1}$ : 3209 (-NH str.), 3045 (C-H str.), 1607(C=C aromatic.), 801-843 (CCl str.)

${ }^{1} \mathbf{H}$ NMR(DMSO-d $\left.{ }_{6}\right): \delta, 3.31\left(2 \mathrm{H}, \mathrm{s}, \mathrm{CH}_{2}\right), 6.95(1 \mathrm{H}, \mathrm{s}, \mathrm{NH})$ 7.21-7.59 (4H, aromatic).

6,7-Dichloro-3-\{[(2,4,5-trichlorophenyl)sulfanyl]methyl $\}$ - $1 \mathrm{H}$-pyrido [3,2-e][1,3,4] oxadiazine $(\boldsymbol{b})$<smiles>Clc1cc(Cl)c(SCC2=NNc3cc(Cl)c(Cl)nc3O2)cc1Cl</smiles>

Synthesis procedure remains same as compound (a), but starting ester is 3, 5, 6trichloropyridin-2-yl [(2, 4, 5-trichlorophenyl) sulfanyl $]$ acetate. The yield of crystalline solid was $70 \%$, melting point was $212-213^{\circ} \mathrm{C}$.

Spectral data

IR (KBr) $\boldsymbol{V}_{\max }$ in $\mathbf{~ c m}^{-1}$ : 3205 (-NH str.), 3038 (C-H str.), 1605(C=C aromatic.), 804-841 (CCl str.)

${ }^{1} \mathbf{H}$ NMR(DMSO-d $\left.\mathbf{d}_{\mathbf{6}}\right): \delta, 3.01\left(2 \mathrm{H}, \mathrm{s}, \mathrm{CH}_{2}\right), 7.41(1 \mathrm{H}, \mathrm{s}, \mathrm{NH})$ 7.21-7.59 (3H, aromatic)

6,7-Dichloro-3-[(naphthalene-1-yl-sulfanyl)methyl]-1H-pyrido[3,2-e][1,3,4] oxadiazine $(\boldsymbol{c})$

Synthesis procedure remains same as compound (a) above but starting ester is 3, 5, 6trichloropyridin-2-yl (1-naphthylthio) acetate. The yield of crystalline solid was 65\%, melting point was $133-134{ }^{\circ} \mathrm{C}$.

6,7-Dichloro-3-(4-chlorophenyl)-1H-pyrido[3,2-e][1,3,4] oxadiazine (d)

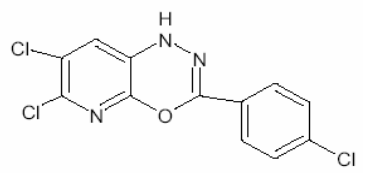

Synthesis of 3,5,6-trichloropyridin-2-yl 4-chlorobenzoate

To 1 necked $250 \mathrm{~mL}$ round bottom flask, $50 \mathrm{~mL}$ dichloromethane solvent and TBAB catalyst was taken and then to this $21.5 \mathrm{~g}$ ( 0.1 mole) of ammonium salt of 3,5,6-trichloro -pyridine-2ol was added. It was stirred using magnetic stirrer. It was thin white slurry. To this, $19.25 \mathrm{~g}$ ( 0.11 moles) of 4-chloro benzoyl chloride was added slowly over 15 minutes. The addition of acid chloride was exothermic and hence temperature was controlled at $30-42{ }^{\circ} \mathrm{C}$. After addition of acid chloride, reaction mass becomes thin with fine salt (ammonium chloride) precipitation. Further reaction was maintained at $40-42{ }^{\circ} \mathrm{C}$ for $4 \mathrm{~h}$. To this mass $100 \mathrm{~mL}$ of water was added and stirred. Separated layers and organic layer washed with $50 \mathrm{~mL}$ of $5 \%$ $\mathrm{Na}_{2} \mathrm{CO}_{3}$ solution to remove any unreacted acid part. Organic layer further washed with water and dried over $\mathrm{CaCl}_{2}$. Product in dichloromethane solvent was concentrated to below $50{ }^{\circ} \mathrm{C}$ to remove solvent part and crude product re-slurried with $100 \mathrm{~mL}$ methanol was filtered. The yield of white crystalline solid was $92 \%$, melting point was $118-119^{\circ} \mathrm{C}$.

The reaction with hydrazine hydrate to hydrazonoate was remains same as compound (a). Cyclization of hydrazonate intermediate to 6, 7-dichloro-3-(4-chlorophenyl)-1H-pyrido [3,2e] $[1,3,4]$ oxadiazine remains same as that we followed in the compound (a). The yield of white crystalline solid was $61 \%$, melting point was $173-175^{\circ} \mathrm{C}$. 


\section{Spectral data}

IR (KBr) $\boldsymbol{V}_{\max }$ in $\mathbf{~ c m}^{-1}$ : 3283 (-NH str.), 2983 (C-H str.), 1595(C=C aromatic.), 827-855 (CCl str.).

${ }^{1} \mathbf{H}$ NMR(DMSO-d $\left.{ }_{6}\right): \delta, 7.27(1 \mathrm{H}, \mathrm{s}, \mathrm{NH}) 7.43-7.78$ (5H, aromatic). GC-MS: $317(\mathrm{M}+1$ peak $)$.

6,7-Dichloro-3-methyl-1H-pyrido [3,2-e][1,3,4] oxadiazine(e)<smiles>CC1=NNc2cc(Cl)c(Cl)nc2O1</smiles>

Synthesis of 3,5,6-trichloropyridin-2-yl acetate

To 1 necked $100 \mathrm{~mL}$ round bottom flask, $50 \mathrm{~mL}$ dichloromethane solvent, DMAP catalyst was taken and then to this $16.0 \mathrm{~g}$. (0.075 mole) of ammonium salt of 3,5,6-trichloro pyridine-2-ol was added . It was stirred using magnetic stirrer. It was thin white slurry. To this $7.06 \mathrm{~g}$ ( 0.09 moles) of acetyl chloride was slowly added over 5 minutes. The addition of acid chloride was exothermic and hence temperature controlled between $30-42{ }^{\circ} \mathrm{C}$. After addition of acid chloride, reaction mass becomes thin with fine salt (ammonium chloride) precipitation. Further reaction was maintained between $40-42{ }^{\circ} \mathrm{C}$ for $4 \mathrm{~h}$. To this mass 50 $\mathrm{mL}$ water was added and stirred. Separated layers and organic layer washed with $25 \mathrm{~mL}$ of $5 \% \mathrm{Na}_{2} \mathrm{CO}_{3}$ solution to remove any unreacted acid part.

Organic layer further washed with water and dried over $\mathrm{CaCl}_{2}$. Product in dichloromethane solvent was concentrated to below $50{ }^{\circ} \mathrm{C}$ to remove solvent part and crude product was re-slurried with $50 \mathrm{~mL}$ methanol and filtered. The yield of white crystalline solid product was $77.7 \%$.

The reaction with hydrazine hydrate to hydrazonoate remains same as compound (a). In a reaction set up of single necked flask, magnetic stirring and oil heating system, $5.0 \mathrm{~g} \mathrm{(0.02}$ mole) of above prepared hydrazonoate, $25 \mathrm{~mL}$ pyridine was added heated to reflux at 115-116 ${ }^{\circ} \mathrm{C}$ and maintained for $6 \mathrm{~h}$. Pyridine was distilled out under reduced pressure and to the left over residue $50 \mathrm{~mL}$ dichloromethane solvent $+50 \mathrm{~mL}$ water was added. Separated layers and organic layer washed with $25 \mathrm{~mL}$ of dilute sodium carbonate solution followed by water. Organic layer concentrated and crystallized with $10 \mathrm{~mL}$ of isopropyl alcohol. The yield of offwhite crystalline solid was $68.8 \%$, melting point was $173-174{ }^{\circ} \mathrm{C}$.

6,7-Dichloro-3-(2-chlorophenyl )-1H-pyrido[3,2-e][1,3,4] oxadiazine ( $\boldsymbol{f})$<smiles>Clc1ccccc1C1=NNc2cc(Cl)c(Cl)nc2O1</smiles>

Synthetic procedure was remains same as $(\mathbf{d})$. The yield of off-white crystalline solid was $65.5 \%$, melting point was $175-177{ }^{\circ} \mathrm{C}$.

\section{6,7-Dichloro-3-phenyl-1H-pyrido[3,2-e][1,3,4] oxadiazine (g)}

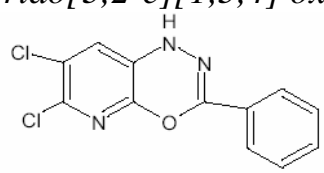


In a one necked $250 \mathrm{~mL}$ round bottom flask, $50 \mathrm{~mL}$ of dichloromethane solvent, TBAB catalyst was taken and then to this $10.8 \mathrm{~g} \mathrm{(0.05} \mathrm{mole)} \mathrm{of} \mathrm{ammonium} \mathrm{salt} \mathrm{of} \mathrm{3,5,6-trichloro} \mathrm{-}$ pyridine-2-ol was added. It was stirred using magnetic stirrer. It was thin white slurry. To this $7.8 \mathrm{~g}$ ( 0.55 moles) of benzoyl chloride was added slowly over 15 minutes. The addition of acid chloride was exothermic and hence temperature controlled between $30-42{ }^{\circ} \mathrm{C}$. After addition of acid chloride, reaction mass was becomes thin with fine salt (ammonium chloride) precipitation. Further reaction was maintained between $40-42{ }^{\circ} \mathrm{C}$ for $4 \mathrm{~h}$. To this mass $100 \mathrm{~mL}$ water was added and stirred. Separated layers and organic layer washed with $40 \mathrm{~mL}$ of $5 \% \mathrm{Na}_{2} \mathrm{CO}_{3}$ solution to remove any unreacted acid part. Organic layer further washed with water and dried over $\mathrm{CaCl}_{2}$. Product in dichloromethane solvent was concentrated to below $50{ }^{\circ} \mathrm{C}$ to remove solvent part and crude product re-slurried with 100 $\mathrm{mL}$ methanol and filtered. The yield of white crystalline solid was $93.9 \%$.

In a set up of one necked $50 \mathrm{~mL}$ round bottom flask with magnetic stirrer, $25 \mathrm{~mL}$ methanol, 0.013 moles of 3,5,6-trichloropyridin-2-yl benzoate and $0.1 \mathrm{~g}$ PTSA was added. It was slurry. This mass was cooled to $18-20{ }^{\circ} \mathrm{C}$ by external cooling and to these 0.015 moles of hydrazine hydrate ( $80.0 \%$ solution) was added. Addition was exothermic and thin slurry converted into thick white slurry. This was maintained at $20-30{ }^{\circ} \mathrm{C}$ for $4 \mathrm{~h}$. Reaction mass concentrated under reduced pressure at $45-50{ }^{\circ} \mathrm{C}$. To this concentrated product $25 \mathrm{~mL}$ of pyridine was added and refluxed for $6 \mathrm{~h}$. Then pyridine was distilled out under vacuum at $100-105{ }^{\circ} \mathrm{C}$. To the residual part, water was added and filtered the product. The isolated crude product purified in $25 \mathrm{~mL}$ of methanol. The yield of buffer white solid was $62 \%$, melting point was $175-177^{\circ} \mathrm{C}$. GC-MS: $283(\mathrm{M}+1$ peak).

\section{Results and Discussion}

The chiral acid mixture (3-(2, 2-dihalovinyl)-2,2-dimethyl cyclopropane carboxylic acid) used in the synthetic process was obtained from M/s Gharda Chemicals Ltd. The chiral mixture was resolved to get single isomer as well as recemic mixture for experimental purpose. The isolated acid was converted into acid chloride by reacting with thionyl chloride under controlled condition to preserve chiral purity. The input raw material i.e. 3,5,6trichloropyrine-2-ol was obtained from M/S Gharda Chemicals Ltd. This 3,5,6trichloropyrine-2-ol (198.5 g, 1.0 mole) was taken in $500 \mathrm{~mL}$ methanol solvent and dry ammonia gas at $30-35^{\circ} \mathrm{C}$ was passed till ammonical $\mathrm{pH}$. This was further refluxed for $1.0 \mathrm{~h}$ and then filtered at $30{ }^{\circ} \mathrm{C}$ to get ammonium salt. 3,5,6-trichloropyridin-2-yl-3-(2,2dihalovinyl)-2,2-dimethylcyclopropanecarboxylate was prepared by reacting corresponding acid chloride with 3,5,6-trichloropyrine-2-ol ammonium salt in dichloromethane solvent in presence of DMAP catalyst at $40{ }^{\circ} \mathrm{C}$. The quantity of ammonium salt taken was $10 \mathrm{~mL}$ excess than acid chloride and dichloromethane solvent was $100 \mathrm{~mL}$ per 0.05 mole scale. Similarly other carboxylates and sulfanyl acetates were prepared. Reacting 0.05 moles of these intermediate in $50 \mathrm{~mL}$ methanol and 0.055 moles of $80 \%$ hydrazine hydrate at $20{ }^{\circ} \mathrm{C}$ using PTSA catalyst, prepared the corresponding hydrazonoates. The novel derivatives of synthesized oxadiazine likely to show diverse biological activity.

\section{Acknowledgement}

The author wishes to express their sincere thanks to Dr.K.H.Gharda, Chairman \& Managing Director of Gharda Chemicals for his continuous encouragement and also to utilize the chemicals and other facility. We are also thankful to Shivaji University Kolhapur and the management of KLE college of Pharmacy for their support to complete this research work. 
Thanks are also due to Dr.K.Sonawane \& Dr. Kishor Bhat for providing spectral analysis and antibacterial study respectively. The author also wishes to mention thanks to Mr.D.K.Shenoy \& Mr. Vidyasagarn for their support.

\section{References}

1. Monica Barbarica, Sandra Kraljevic, Magdalena Grce and Branka Zorc, Acta Pharm., 2003, 53,175-186.

2. Phillip T Berkowitz, Robert A Long, Phoebe Dea, Roland K Robins and Thomas R Matthews, J Med Chem., 1977, 20, 134-1138.

3. Khan K M, Rahat S and Choudhary M I, Chim Acta., 2002, 85, 559-570.

4. Kornet M J, J Heterocycl Chem.,.1996, 33, 2047-2049.

5. Robinson R P and Donahue K M, J Heterocycl Chem.,1994, 31, 1541- 1544.

6. Gravestock M B, Eur Pat Appl.EP, 265169, 27; Chem Abstr., 1988, 109, 110-160d.

7. Jednkovitis, Andrea Urogdi et al. US patent 6384029.

8. Lapied B, Grolleau and Sattelle D B, British J Pharmacol., 2001, 132(2), 587-595.

9. Stephen F Mc Cann, Gary D Annis et al., Pest Manag Sci., 2001, 57 (2), 153-164.

10. Sicardi S M, Lamdan S and Gaozza CH, J Pharma Sci., 1974, 63(8), 1336-1337. 


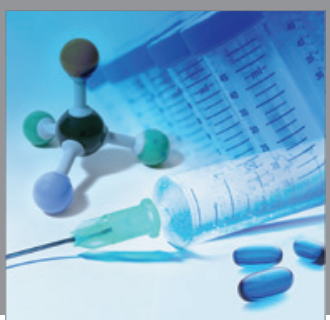

International Journal of

Medicinal Chemistry

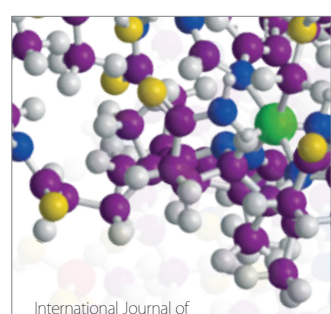

Carbohydrate Chemistry

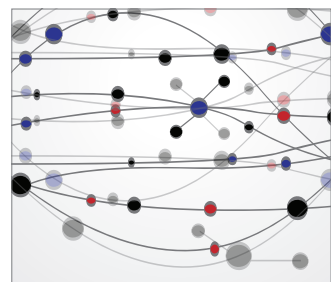

The Scientific World Journal
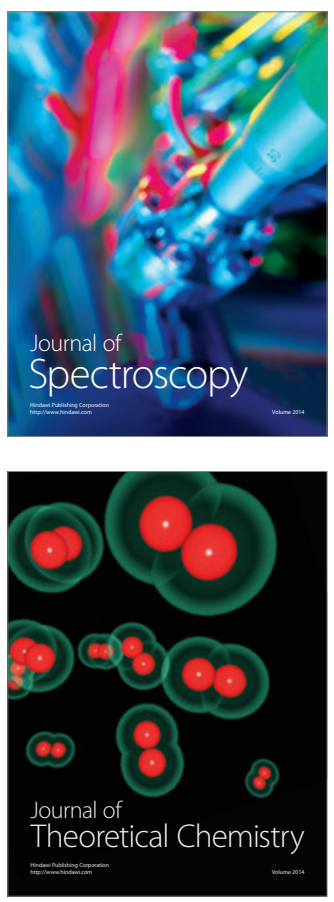
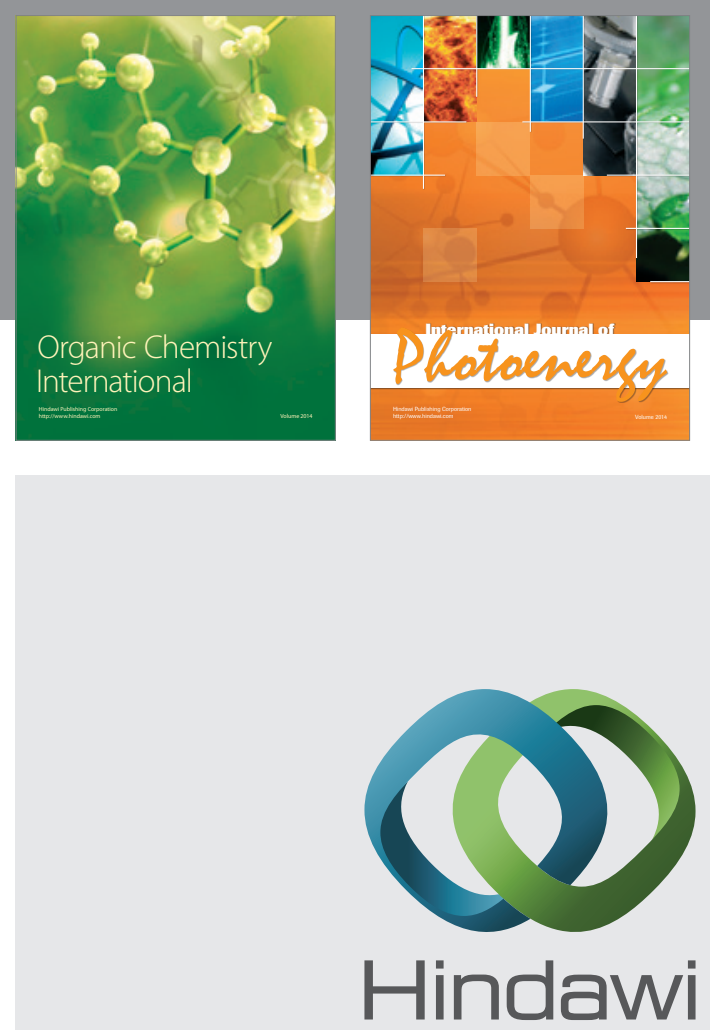

Submit your manuscripts at

http://www.hindawi.com
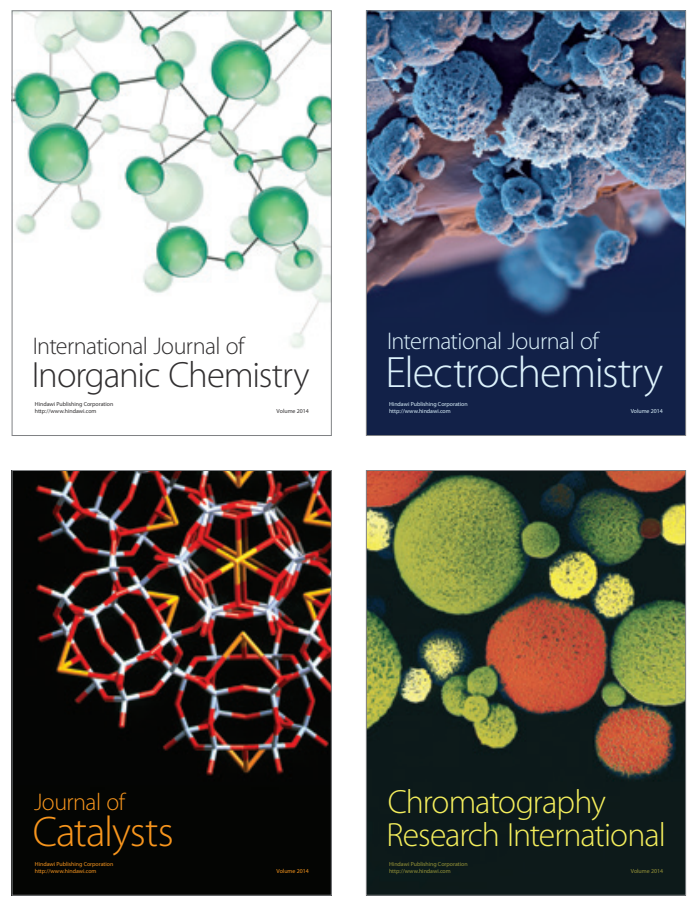
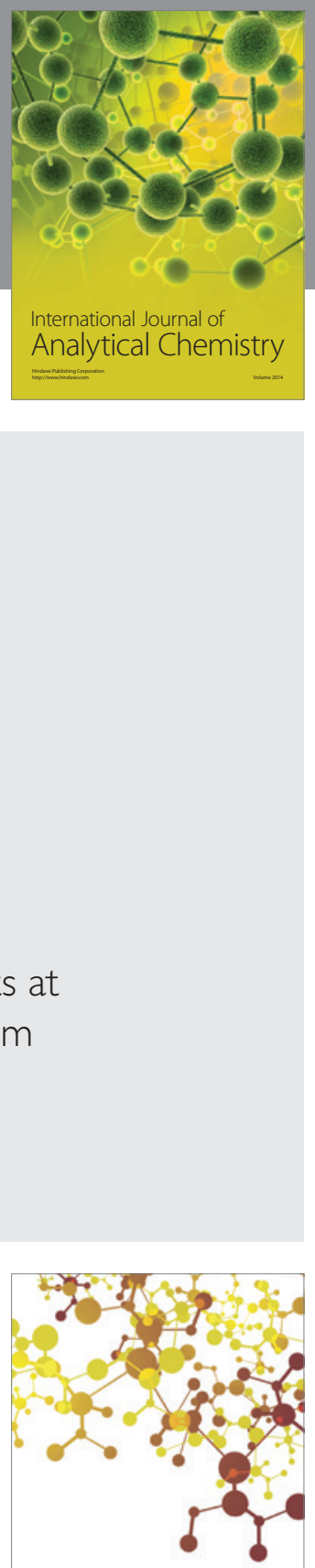

Journal of

Applied Chemistry
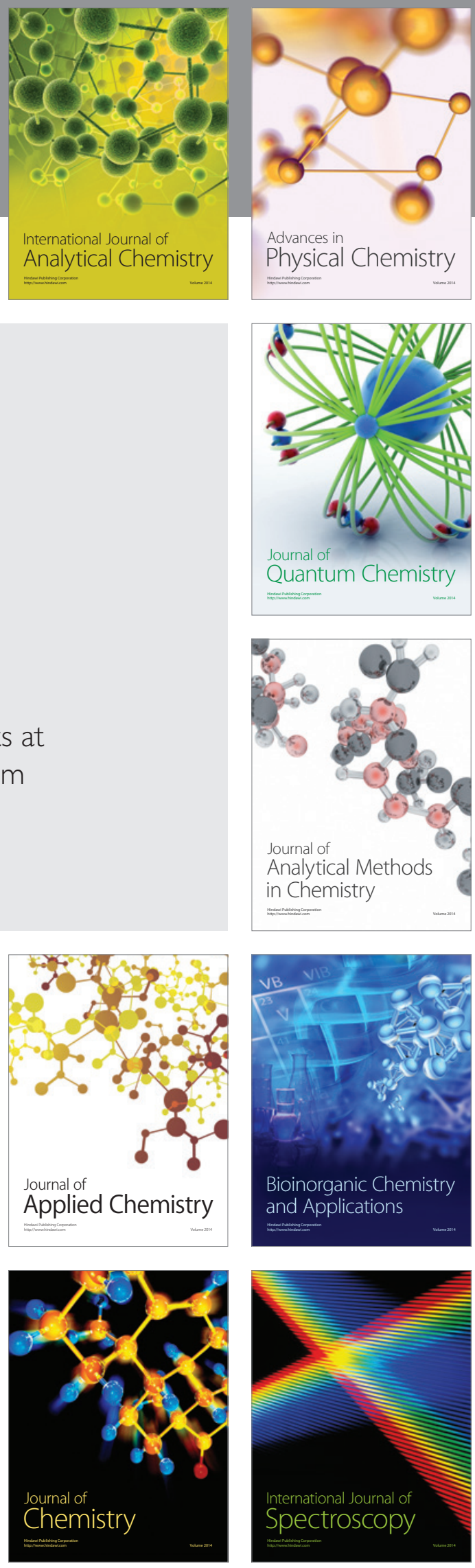